\begin{tabular}{|c|c|}
\hline $\begin{array}{l}\text { ÇÜTAD } \\
\text { Cukurova Üniversitesi } \\
\text { Türkoloji Araștırmaları Dergisi }\end{array}$ & $\begin{array}{c}\text { Cilt 4, Sayı } 1 \\
\text { Haziran } 2019\end{array}$ \\
\hline $\begin{array}{l}\text { ISSN: } 2587-1900 \\
\text { E-ISSN: } 2548-0979\end{array}$ & $\begin{array}{l}\text { Geliş Tarihi: } 15.03 .2019 \\
\text { Kabul Tarihi: } 13.05 .2019\end{array}$ \\
\hline \multicolumn{2}{|c|}{$\begin{array}{l}\text { Makale Künyesi (Çeviri): Polat, Ü. (Çev.) (2019). Fatih Emirhan } \\
\text { mektupları. Çukurova Üniversitesi Türkoloji Araştırmaları Dergisi. } 4 \text { (1), } \\
\text { 202-225. }\end{array}$} \\
\hline
\end{tabular}

\title{
FATİH EMİRHAN MEKTUPLARI
}

\section{Fatih EMIRHAN Aktaran: Ülkü POLAT ${ }^{1}$}

\begin{abstract}
ÖZET
Fatih Emirhan 19. asrın sonu ve 20. asrın başlarında Tatar edebiyatının özellikle nesir türünde ön plana çıkmış isimlerinden birisidir. 20'li yaşlarında felç geçirmiş, ömrünü tekerlekli sandalyede sürdürmüştür. Emirhan, gazetecilik faaliyetleriyle de ön plana çıkmış, birçok yazar ve şairi desteklemiştir. Yazar medreseden arkadaşı Rizvan İbrahimov'a (Aluşi), İsmail Aitov'a, Mecit Gafuri'ye ve çeşitli kişilere pek çok mektup yazmıştır. Emirhan'a ait bu mektuplar SSSR Fenler akademisinin Kazan, dil, edebiyat ve tarih enstitüsü arşivinde saklanmaktadır. Yazarın doğumunun seksenci yılı münasebetiyle H. Hismetullin bu mektuplardan bazılarını Kazan Utları dergisinin 1966 yılı Ocak sayısında yayımlanmıştır. Fatih Emirhan'ın yakın çevresine gönderdiği bu mektuplarda yazarın hayatı ve edebi faaliyetleriyle ilgili pek çok bilgi bulunmaktadır.
\end{abstract}

Anahtar kelimeler: Fatih Emirhan, Tatar Edebiyat1, Tatar Matbuat1.

\section{FATIH EMIRHAN'S LETTERS}

\begin{abstract}
Fatih Emirhan is one of the prominent figures of Tatar literature especially in prose in the late $19^{\text {th }}$ and early $20^{\text {th }}$ century. Emirhan had a stroke in his twenties and continued his life in a wheelchair. Emirhan also worked in journalism and supported many writers and poets. He wrote letters to Rizvan İbrahimov ( a friend of him from his madrasah), İsmail Aitov to Mecit Gafuri and many other names. These letters belonging to Emirhan are kept in the archives of Kazan, language, literature and history institute of SSSR Science Academy. Hismatullin published some of these letters in the January issue, 1966 dated in the journal of 'Kazan Utları' on the occasion of the eighth year of the author's birth. In these letters sent to the immediate surroundings of Fatih Emirhan, there is a lot of information about his life and his literary activities.
\end{abstract}

Key words: Fatih Emirhan, Tatar Literature, Tatar Press.

\footnotetext{
${ }^{1}$ Kilis 7 Aralık Üniversitesi, Öğr. Gör. Dr. ulkupolat@kilis.edu.tr https://orcid.org/0000-0002-3304-1939
} 
Son yıllarda matbuatta Fatih Emirhan'ın çeşitli yıllarda yazılmış ve çeşitli kişilere gönderilmiş pek çok mektubu basıldı. «Kazan Utları» dergisinin bu sayısında ünlü yazarımızın yeniden birkaç mektubunu yayımlıyoruz. O mektuplarda Fatih Emirhan'ın fikri gelişimi ve ictimâî meselelerle gençliğinden beri ilgilenmesi, bundan yarım asır önce Tatar matbuatının durumu, ilk gösterilerin meydana çıkışı, Tatar genç entelektüellerinin manevi duyguları belirir. Kazan Utları dergisinin bu sayısında ünlü yazarımızın yeniden birkaç mektubunu yayımlıyoruz. O mektuplarda Fatih Emirhan'ın fikri gelişimi ve sosyal meseleler ile ilgisi bundan yarım asır önce Tatar matbuatının durumu, ilk gösterilerin meydana çıkışı, Tatar genç, aydın sınıfının manevi duyguları belirir.

Fatih Emirhan, M. Gafuri’nin Ekim Devrimine kadar yazılmış birçok eserini tenkit etmişti. Ekim Devriminden sonraki çağda, M. Gafuri'nin sanatı sağlam bir şekilde gelişti. O gerçek manâda ihtilal hatibi oldu. Fatih Emirhan'ın Gafuri'ye gönderdiği kutlama mektubunda onun sanatındaki bu başarıyı sağlam bir şekilde idrak ve takdir etmişlik açıkça seziliyor.

Burada verilen mektupların hiçbiri şimdiye kadar tam olarak basında çıkmamıştır. Sadece Fatih Emirhan'ın sanatı hakkındaki çalışmalarda ve makalelerde mektuplardan parçalar ve belgeler kullanılmıştır. Mektuplar SSSR Fenler Akademisinin Kazan Dil, Edebiyat ve Tarih Enstitüsü arşivinde saklanmaktadır. M. Gafuri adına yazılan mektup yeni stil ile sunuluyor. Fatih Emirhan'ın henüz Sovyet matbuatında ve umumi matbuatta yayımlanmamış mektupları çeşitli zamanlarda çeşitli vesilelerle yazdığı hatıraları çok. Bunlar da gelecekte yayımlanır diye düşünüyoruz.

H. Hismetullin, 20 Şubat 1904.

Muhterem dostum R. Aluşi ${ }^{2}$

Esselamu aleyküm!

Zatınızın mektubu geldiğinde, çok sevindim. İdadi ${ }^{3}$ sınıfı arasında ortaya çıkan medrese ihtilali plansız olduğu için, medresenin ıslahına hizmeti olmadı denecek derecede az oldu. Hatta reisleri, heyecandan başı helak olan Kasim, damollaya ihtilalin sebeplerinden birisinin

2 Rizvan İbrahimov (Aluşi) - F. Emirhan'ın medresede birlikte okuduğu arkadaşı. Sovyet döneminde Ufa'da Komvuz'da ders verir, 1938 yılında ölür.

3 Eski medreselerde ibtidan (başlangıç), rüşdi, idadi, ali, diye adlandırılan basamaklar olurdu. 
idadi sınıfina mantık okutulmaması olduğunu belirtmiş, eğer mantık dersi gelirse isyanı durdururuz diyerek bütün idadi sınıfları için mantık iltizam etmişti. Artık, elhamdülillah, o delikanlı aliye cemiyeti $^{4}$ tarafindan verilen dilekçede dikkat çekilen ifsade medresesi ${ }^{5}$ için millet meclisi tarafindan azledildi.

$\mathrm{Bu}$ ihtilalin faydası olarak, medrese idaresi için öğretmenlerden mürekkep bir millet meclisi oluşturularak damollaların istiklali tamamen selb edildi ${ }^{6}$.

Tamamen medrese öğrencilerinden mürekkep bir topluluk teşkil edildi. Şimdi yetmiş beş kadar üyesi vardır. (Gizli tutulsun.)

Öğrenciler ve lisede okuyan kızlar ile geçen yılın başında Tatar lisanında iki oyun sahneledik. Birisi «Kızganıç Bala"», birisi "Gıyşık Belass ${ }^{8}$ ». Ben «Kızganıç Bala»da Halil rolünde oynadım, «Gıyşık Belası»nda Gabdis-Samat Efendi olarak oynadım. Halk tarafından ilgiyle karşılandı. Bayramın üçüncü gününde de iki oyun oynarız inşallah.

Sonsuz sadakat.

Fatih.

24 Ekim 1906, Moskova.

Aziz dostum Rizvan, sana selamlar olsun!

Ben 22 Ekimde Moskova'ya geldim ve malum işe ${ }^{9}$ başladım. Kazan'da olduğum sırada senden bir mektup (paralı) ve bir telgraf alarak kendim de düğüne ${ }^{10}$ bir tebrik kartı göndermiştim, fakat 5 Ekim tarihli yine açık bir mektubunu alarak, o kartın ulaşmadığını anlayıp teessüf ettim. Buna göre seni ve Ferhane Hanımı yeni hayat ve

\footnotetext{
${ }^{4}$ Dördüncü sınıftaki öğrenciler.

${ }^{5}$ Medreseyi tahrip etmek, dağıtmak.

${ }^{6}$ Baş mollanın müstakil çalışma hukukuna son verildi.

${ }^{7}$ Zavallı Çocuk.

${ }^{8}$ Aşk Belası.

${ }^{9}$ Dergide sekreterlik işi.

${ }^{10}$ Ferhane ile Rizvan'ın düğünü, Ferhane uzun yıllar Sibirya mekteplerinde öğretmen olarak çalışır. 1958'de Ufa'da ölür.
} 
birbirinize uygun yoldaşlığınız ile tebrik ettiğimi ve her ikinizi mutlu ve talihli görmek maksat ve isteğim olduğunu arz ediyorum.

Mektebin intizamlı oluşu ve kızlar bölümünün de vücuda geldiği haberi beni de çok sevindirdi. Çalış, kardeşim, çalış, çalışmakta ancak talih.

Moskova'ya geleli iki gün oldu. Zahid Efendi ${ }^{11}$ sayesinde vakit pek rahat geçti. Zahid Efendi beni çok iyi karşıladı. O ve muallimeler tipik editör, bürokrat gibi değil başka arkadaşlar gibi keyifli insanlar. Şimdi Moskova'nın en güzel yerlerinden birinde (Petrovka) Meryem Şamil ${ }^{12}$ konağında bir konuk odasında ikamet ediyorum.

Kazan'da sen gittikten sonra bilmediğin herhangi bir durum olmad, veya olduysa da, aklımda kalmadılar, buna göre ben gitmeden evvel olan durum ve hislerimi yazacağım. Ekimin onundan sonra maddi durum epey fazla kötüleşmiş ve babam ile aramız tamamen soğumuştu. Hatta gideceğim gün babamın bana karşı her hareketinden bir soğukluk ve sen bizden tamamen ayrılıp gidiyorsun, kötü talih der gibi bir şey seziliyordu ve her dakika beni evden soğutuyor, uzaklaştırıyordu. Diğer taraftan annemin müşfikâne ve annelere has muamelesi ve gitmeden evvel gözleri yaşlı halde «oğlum, sen bize öfkelenme ve mektup yaz» sözleri benim de gözüme yaşları getiriyor ve anaların çocuklarına olan münasebetlerini bana pek açık gösteriyordu. Velhasıl, bir taraftan, eve yakın da tutmayan dikenler ve bir taraftan da, pek sağlam çeken rüzgârlar beni pek huzursuz bir ruh haline düşürüyordu. Böylece evimden ayrıldım ve Cuma günü (20 Ekim) istasyona geldim. Benden önce uğurlamaya arkadaşlar gelmişlerdi, beklediler, söyleştik, dertleştik, sevindik, trenin gitme vakti yakınlaştı, arkadaşlar son sözlerini söylediler, öpüştük ve gittim. Hakikaten zor anlardı, yalnızlaştığımı hissettim.

Bir saat yerimden kalkmadan gitmeye ve kalbimde hislerimi kendime anlatmaya mecbur oldum ki, sonuç şöyleydi: "Dostlarımdan ayrılıyorum, dünyada beni en yakın gören bir yüreğe acı veriyorum zor. Kazan'dan ve onun Tatarlarından ${ }^{13}$ kurtuluyorum - sevinç. Çalışmaya başlarım, istidâdımı görürüm — ıdırap ve meçhullük”.

\footnotetext{
${ }^{11}$ Zahid Şamil- 19. Asırda Dağıstan'da özgürlük hareketine liderlik etmiş Şeyh Şamil'in oğlu «Terbiyetěl-Etfal» adlı çocuk dergisinin (1907, Ocak-Nisan) editörü.

${ }^{12}$ Meryem Şamil —Zahid Şamil'in kız kardeşi.

${ }^{13}$ Fatih Emirhan'1 kendi çevresinden kuşatan hatıra, özgür olmama hissi epey biktırmıştı.
} 
Tren gidince biraderim İbrahim'in ${ }^{14}$ söylediği söz bana da bir tuhaf hal veriyor ve aczimi hissetmeye vesile oluyordu. Onun sözü şöyleydi: "Abi beni unutma, biliyorsun babamın muamelesini, sen gidince, benim için daha zor olur ${ }^{15 \text { ”. }}$

Şans eseri, yolda öğrenciler ve meslektaşlarla karşılaşıp, onlarla tanışınca kısa süreliğine de olsa ağır hisler unutuldular.

Aitov İsmail ${ }^{16}$ bu son günlerde bana pek soğuklaşmıştı; sebebi ise böyle işsiz yaşamak ve ahlaka uygun davranmadığını söylemem. Başka ne yazayım kardeşim. Resim göndereceğini söylemişsin, pek intizâr ile bekliyorum. Ben de gönderirim, bu günlerde resim çektiririm.

Ferhane Hanıma selam söyleyip, dualarını rica ediyorum.

II

Eğer «Terbiyetěl-etfal»e müşteriler bulunur diye düşünüyorsan, abone defteri göndeririz. Yüzde on kadar hizmet mükâfatı veririz. Perakende satmak için aldırmak mümkün. Derginin önceki sayısı (numune) aralık ayının başına kadar çıkacak. Ocak ayı başında düzenlenip çıkmaya başlayacak. Yıllık tutarı 5 sum. Her ay iki dergi. Birkaç pedogojik yaprak, takvim ve başka birkaç şey hediye edilecek.

Redaksiyonun adresi: Moskova, Tsvetnoy Bul. D. Baybekova Red. Tatarskogo jurnala «Terbiye-i Etfal».

Bana mektup yazdığında: «Fatihěl Emirhaniye mahsus» kaydını eklersin. Mektup bekliyorum.

Sonsuz sevgiler

Fatih-ěl Emirhani.

9 Aralık 1906, Moskova.

Kardeşim Rizvan, çok saygıdeğer Farhanya Hanım!

\footnotetext{
${ }^{14}$ Fatih Emirhan'ın küçük erkek kardeşi, 1918'de Komünistler partisine katılır, Stalin yıllarında tevkif edilmişsir.

${ }^{15}$ Bu sözler Fatih Emirhan'ın "Gençler" (1909) oyunundaki Aziz ve Yusuf'un durumunu hatirlatiyor.

${ }^{16}$ İsmail Aitov (1888-1930) - Söleyman Aitov'un oğlu. İkinci bir mektubunda Fatih Emirhan'ın onu "tipik bir zengin oğlu" olarak anar.
} 
Sizlere selamlarım!

Gönderdiğin hediye - fotoğrafını aldım, her ikinize de halis teşekkürlerimi arz ediyorum. Fotoğraftaki güzel yüzler gerçekten herkesin dikkatini celp etmeliktir. Fakat delikanlılarda seyreklik görünüyor, yeniden bir delikanlı eklense, etki kâmil olurdu. Fotoğrafa mizah kabulünden de bir eleştiri yapmak istiyorum: Öncelikle: Rizvan'ın minder üstüne oturuşu bana Huvalin ilçesindeki köy mollalarını hatırlatıyor. Acaba, Rizvan sen de o taraflardan misın? İkinci olarak: Ferhane Hanımın boynunda senin kolunu görüp şaşılacak derecede korktum (kahrolası), acaba Rizvan Ferhane Hanımı boğmak mı istemiş? Üçüncü olarak: Hürmetli Aleksandra Vnnitskaya'ya söyleyiniz: Ferhane Hanımın kalp atışını dinleyen sağlık memurunu fotoğrafta o pek başarılı gösteriyor.

Rizvan, hatırla şimdi Fatıyma Kuliyeva'yı; Rehime Hanımı ben ilk defa gördüğümde «Tamam bu Fatıyma olsa gerek» - diye düşünüyorum yazdım. Dördüncü olarak: Nasıl hepiniz de, ömrünüzde hiç fotoğraf görmemiş gibi, ona baktınız?

Ha, ha, ha!

Ama bu şaka.

Bana fotoğrafta çok benzeyen bir şey var: $\mathrm{O}$ da - hepinizin sade kıyafetlerde, demokrat görünümde olmanızdır.

Mektubunuzdan mutlu haberler öğrendiğime göre, bu mektup benim için çok değerliydi: Ferhane Hanım ile tabiatınızın böyle uyumlu olması ikinizin de saadetinizi temin eden şeydir.

Cenâb-1 hak devamını hâsıl etsin!

Aslında ben önceden de böyle olur diye düşünmüştüm. Çünkü, öncelikle sen ahlaksız birisi değilsin. Ve ikinci olarak da - Ferhane Hanımın resminin bana anlattığı şey tam olarak yumuşak yaratılışlı birisi olacağını bildiriyordu.

Elbette, değerlilerim, siz talihli kişilersiniz!

Rizvan, sen bana «fotoğraf dikkatini çekecek olmasa da...» diye yazmışsın. Tamamen boşuna, sadece benim değil, belki bütün redaksiyondaki kişilerin dikkatini çekti.

Moskova'daki hayatım: 
Moskova'daki Tatar ve hatta Rus aristokratlarından, hatta bürokratlarından pek çok aile ile tanıştım. Her akşam eğlencelerde, balolarda karşılaşılıyor. Bunlar ne kadar iğrenç... Vakitlerden birinde Şamillerde eğlencede bir general kızı - gencecik bir kız ile tanıştım. Onunla biraz dans ettik, konuştuk. Vesaire. İşte bir vakit bunlarda konuk olduk. Bu kız beni bir odaya çağırıp şöyle sordu: «Ben sizden bir şey sorarsam, ayıplamaz mısınız? Ve doğru cevap verir misiniz?» Ben de pek aristokrat tavırla: «Şüphesiz» - diye cevap verdim. (Şimdi güzelce dinle!) «Bana söylediler, siz sosyalist misiniz? Bu söz doğru mu, değil mi? Ben umut ediyorum: Yalandır!» Ben cevap verdim: «Evet, dosdoğru.» Kız korkup gitti. Biraz sonra: «Peki siz, böyle saygılı ve hiç tehlikeli değilsiniz elbette.» Ben: «Siz bütün sosyalistler tehlikeli diye mi düşünüyorsunuz?» O: «Şüphesiz.» Isşte şu ruh halinde yarım saat konuşup zar zor anlattım ki sosyalistlerin rastladığı birini öldüren kişi olmadığını.

Artık sen düşün, bana nasıl topluluklarda bulunmak nasip oluyor. Öyle zamanlar oluyor ki, şu aristokrat ve aristokratların davranışlarından (ifade için üzgünüm) kusasıları geliyor. Ama Zahid Efendi, işte o beni anlayan yegâne insan. $\mathrm{O}$ - ilerici, müterakkî.

Hayat burada pahalı. Hemen 60 sum $^{17}$ para buluyorum, şu aristokratlar arasında bulunmaktan dolayı, hepsi harcanıp bitiyor.

Artık o eğlenceleri, baloları bırakıp gerçekten okumaya başlıyorum. Siz benden fotoğraf istemişsiniz.

Çok geçmeden ben size fotoğrafımı gönderirim. Lakin bir şartla: Siz de tenkit yazıp gönderirsiniz.

Kardeşimden mektup alıyorum. İsmail'den haber aldım. Ama Aytuganov'dan ${ }^{18}$ hiçbir haber alamadım.

Bugün Kuliyev'den ${ }^{19}$ mektup aldım, bu arada, o yazıyor: 8 Aralıkta eğer vali izin verirse «Noviy Kulüp»te «Öç Hatın Bělen Tormış ${ }^{20}$ » oyununu sahneleyeceğiz, diyor.

\footnotetext{
${ }^{17}$ Sum: yüz "tiyěn" değerinde Rus parası.

18 Aytuganov İbrahim - tüccar İsmail Aytuganov'un oğlu, gençler arasına katılsa da, yararlı bir iş yapmamıştır.

${ }^{19}$ Kuliyev İbrahim — gazeteci, F. Emirhan'ın gençlik arkadaşlarındandır, 1885 yılında doğmuştur, Stalin yıllarında tutuklanır, zindanda ölür.

${ }^{20}$ Üç Hanım İle Hayat.
} 
Derginin önceki sayısı 15 Aralıkta çıkıyor. Mufassal bir mektup bekliyorum. İşitiyor musun?

Öyleyse bir sonraki mektuba kadar hoşça kal.

Fatih Emirhan.

8 Nisan, 1907, Moskova

\section{Kardeşim Rizvan!}

Martın on sekizinde yazdığın mektubu üçüncü gün aldım, bugün cevap yazmak için acele ediyorum. Kazan'da kaldığım vakitte kaderin zulmü ile yabancı yerlere gönderilen dostlarımın hallerini pek kusurlu değerlendirdiğimi, ancak şimdi kendim onların durumuna düşünce bihakkın bu durumu takdir etmeye başladığımı farkettim. ${ }^{21}$ Her mektup, her bir haber, o taraftan esen her rüzgâr çok değerli, onun için senin mektubunda: «Özledim, Kazan'a dönmene ve görüşmeye ihtiyacım var» diye yazdığın sözler şimdi benim için çok anlaşılan cümlelerden.

Gerçekten de geçen günleri hatıra getirsen aralarında nasıl rahat ve keyifli geçirilen ve vaktinde bi-hakkın takdir edilmeyen günler, akşamlar, geceler var. Nasıl Kuliyev İbrahim'e Oslan'a gidip oynuyorduk. O bizi meyvelerden yapılmış kvas ${ }^{22}$ ile ağırlıyordu. Sen onun eşi ${ }^{23}$ ile huzurlu olmasına özenip Ferhaneyi düşünüyordun.

Nasıl toplanıp Aitovların yazlığında sabah 4-5'e kadar tenkitteki becerimizi yarıştırıp bakıyorduk, nasıl Aytugan İbrahim bize her türlü eğlendirici piyesler anlatıyordu. Nasıl toplanıp Kazanka'ya (Kazan Nehri) yüzmeye gidiyorduk.

Elhasıl, çok eğlenceli vakitler geçiriyorduk. Kazan'a ben 10 Nisanda dönüyorum, eğer siz de dönerseniz o vakitte topluluğumuzun bütün üyeleri eksik kalmazdı. Yazılarında bu yıl Kazan'ın da daha cazip olacağını söylüyorlar.

${ }^{21}$ F. Emirhan Moskova'ya gidişi dolayısıyla yazdığı mektubunda Kazan'dan kurtuluşuna pek sevindiğini bildirmişti.

${ }^{22}$ Kvas: Çavdar ekmeğinden kızartılıp kurutularak yapılan bir içecek.

${ }^{23}$ Söz Fatıyma Kuliyeva hakkında. Bu hanım şimdi de Kazan'da yaşıyor. 
İsmail çok olmadı, Moskova'dan Yalta'ya gitti. Mayısın 10'u gibi Kazan'a dönecek. Ferhane Hanım benim makaleleri okuyormuş. Fakat ben daha çok imzasız gönderiyorum. Bu sebepten, hangilerinin benim makalelerim olduğunu söylemek istiyorum.

Birinci sayıda — «İdareden»; «İstanbul Şehri»; «Gökyüzünde Görünen Nesneler»; «Ayaz»

İkinci sayıda — «İdareden» (Gerekli yerleri kaydedilip saklanmış.)

Üçüncü sayıda — «İdareden»; «Gökyüzünde Görünen Nesneler»

Dördüncü sayıda - «İdareden» (Gerekli yerleri kaydedilmiş.); «Moskova Şehri»; «Galimet-il-benat»; «Mendeleyev»; «Zelzele».

Beşinci sayıda - «İdareden» (Gerekli yerleri saklanmış.); «Petersburg Şehri»; «Gül Ağacı» (Tercüme); «Gökyüzünde Görünen Nesneler»; «Duma açıldı» (En gerekli yerleri saklanmış.). Bundan sonraki sayılarda bazı makalelerimi imzamla yazdım.

Az zaman önce İbrahim'den mektup aldım. Kazan'da beni bekliyorlarmış. Hiç beklemiyordum, Fatıyma Yunısova'dan ${ }^{24}$ da bir mektup aldım. «Acayip özledik, Kazan'a dönünüz» diye yazıyor (şaşılacak şey). Bir sonraki mektubunu Kazan’a yaz. Ferhane Hanıma selamımı söyleyip dualarını rica et!

Sonsuz sevgi ve bekleyiş.

Fatih.

Bugün altıncı mektubu yazdım, yoruldum.

\section{Nisan 1908, Kazan}

\section{Azizim Rizvan!}

Sana karşı yine bin kez günahlıyım. Ben - mektup yazmaya üşenen kişi. Bu gerçek sana da çoktandır malum olsa gerek... Tembellik bir

${ }^{24}$ Fatıyma Yunısova - büyük tüccar ve toprak sahibi Möhemmetrehim Yunısova'nın kızı. Demokratik aydın sınıfı çevresinde dolaşmak o çağdaki zengin kızları arasında moda olmuştur. 
maraz derler. $\mathrm{Bu}$ yüzden kişiyi ayıplamak değil, belki merhamet etmek gereklidir. Sana mektup yazmayı düşüneli en azından bir buçuk ay var. Takdir yetmeyince bir iş yapacak hal yok! Derginin neşri ile alakalı fikir istiyorsun. Bu konuda benim iki yıllık tecrübemle hâsıl olan fikrim şu: 1. Gerek gazete gerek dergi ilk iki yılda her zaman zarara maruz kalır, fakat ondan sonra kendi kendine yetecek dereceye ulaşsa yeter. 2. Eğer gazete ve dergi gelecekte bir geçim kaynağı olsun denirse, kafadan en az 3-5 bin sum paranın elde olması gerek. 3. Neşre başladığında her zaman güzden başlamak gerek. Çünkü ocak ayından başlandığında halk siyasi çizgisini bilmeden, itimat etmeden abone olmuyor. Böylece bahar geliyor. O zaman halkta gazete ve dergi hevesi kalmıyor. İşte böyle, birader!

Görüyorsun, şimdi «Yaña tormış ${ }^{25} »$ (Yeni hayat), nasıl durakladı. Rivayetlere göre bu arada da bin sum zarar edip bitmişmiş.

Yine de, eğer şimdi naşir ve muharrir bulma endişesine düşsen, ben kendim bir iş tavsiye ediyorum: «El-islah» idaresi temmuz başlarında mizah dergisi neşretmeye başlamayı düşünüyordu. Bunu ben sana bırakayım. Şimdilerde faydalı bir dergi varsa, o da mizah dergisidir. İbret için ben sana «El-islah»ın durumundan bir kısım yazıyorum. «El-islah» Ekim ayı başından Nisan başına kadar yani yarım yıl 1400 sum masraf etti. Bu cümleden - muharrirler ve redaksiye 400 sum tutmuş. Demek ki muharrirlere bir de ödenmiyor denecek derecede kötü bir dairede durduğunda bile birçok masraf gereklidir. Şimdi «Elislah» dairesi için 20 sum ödüyor;

Sekreterya........20 sum;

Muharrire.........15 sum;

Ufak masraflar....12-13 sum civarında.

Bizim neşretmeye başlamayı düşündüğümüz on beş günlük mizah dergisine, hazır redaksiye hazır muharrirler üzerinden yılda 1200 sum masraf gerekiyor. Mizah dergisine özellikle «El-islah» isminden neşre başladığımızda o kadar müşteri bulunur diye düşünüyoruz. İşte birader, durumlar böyle. «El-islah» o dergiyi sana biraksa az paha ile redaksiyesinde bir oda birakır. O zamana kadar biraz yararsız katılımcılar da bulunurlar. Eğer ben yaz ve kış Kazan'da kalsam, ben de elimden gelen yardımı yaparım. Onun üstüne Kazan'da başka işlerin de yapıllyor olmasına inansan, belki gidince, güzelce yerleşip

${ }^{25}$ Uralski'de «Fikir» gazetesi durdurulduğunda onun yerine 1907 y1lında çıkarılmaya başlanan gazete. 
kalmak da mümkün olur. Eğer böyle yapmak maksadında isen çabucak dönüp, izin isteyip dilekçe vermeye mecbursun.

Ferhana'ye selam. Çabucak geçse deyip beş vakit namaz ardından dua ediyorum.

Ebedi kardeşin

Fatih.

Halim ortada ${ }^{26}$.

26 Ekim 1908, Kazan.

\section{Dostum,}

Bugüne kadar sana acaba ne kadar mektup yazmam gerekli olup da, şimdiye kadar bir mektup bile yazmadığım için sana karşı çok suçluyum. Lakin, benim bu suçum sadece sana karşı değil, arkadaşlarımın her birine karşı çok malum ve çok eski artık: «Len yosliȟěl-gattarě ma efsedehen-neher» ${ }^{27}$ diyor Araplar.

Önce ben sana durumumu yazmaya başlayayım: Nihayet derecede parasızlık, vasat, güzel dersler ile meşgul olma, biraz yazı, her gün redaksiyonda olma, edebiyat meclisleri bahanesiyle her hafta misafirlik. Ş. K. ${ }^{28}$ hanımı görünce sevinme - işte durumların özeti. Sağlık yavaş yavaş ilerliyor. Mamafih, parasızlıktan birçok vakti gelen tedavileri uygulamadan duruyorum. Sen yazıyorsun (mektup no 1) «El-islah»1 bitirip de, para kazanıp tedavine başla diye ${ }^{29}$. Canım, benim bütün memnuniyetsizliğimde şimdi şu her gün redaksiyona çıkmaktan ibaret olan bölüm, dinlenmek de bu, yaşamak da bu. İşte bunu sen aklından çıkarma.

Şimdi «El islah»1n haline gelelim: Parası yok, hep çeşitli hileler yapmak durumunda kalınıyor (sır tutmak).

\footnotetext{
${ }^{26}$ Fatih Emirhan'ın felç olup sakat kaldığı bundan dolayı tedavi gördüğü ve sağlığının kötüleştiği zamanlar. Halim ortada sözü bu durumla ilgili.

${ }^{27}$ Dünyayı bozanı kader düzeltmez.

${ }^{28}$ Şemsinisa Kamalova -F. Emirhan'nn sevdiği kız, 1918 yllında Kazan'da ölür.

${ }^{29}$ İsmail Antov kendisinin 27/IX 1908 yılındaki mektubunda «Elislah»1 bitirip, tedavi olmayı ve okumayı nasihat eder.
} 
Arkadaşların durumu: Kayyum Kolehmetov' $1^{30}$ üçüncü gün tevkif ettiler. Çok kısa zaman sonra Simbir şehrine sürgüne gönderilecek. Eğer bulabilirsen, biraz para (yardım için) toplayıp gönder (redaksiyon adresine olabilir). «Kazak ${ }^{31} »$ okuyor, çabalıyor, bu günlerde yeni ceket diktirip gönderdi, Gaziz ${ }^{32}$ bu günlerde askeri muayeneye girdi, pek zayıf olduğundan kaldı, o da okuyor, çabalıyor, bir gün okuduğu şeyden ertesi gün söz arasına sıkıştırıp sıkıştırıp yabancıların çokça olduğu yerlerde konuşmaya başlıyor. Soltan ${ }^{33}$ da güzelce okuyor, lakin «Ben nereye gidiyorum ${ }^{34} \gg$ dan da geri kalmıyor, diyorlar. Agiyev ${ }^{35}$ kendini şair olarak düşünüp sevinerek yaşıyor. «Şimdi siz benim şiirlerimi takdir etmeseniz de tarih takdir eder» diye gerçekten kendisi inanıp, insanları da inandırmak istediğini söylüyor. Şimdi Gariflar ${ }^{36}$ ile de iç içeyiz, bayramın dördüncü gününde beni yanlarına çağırmışlardı, gidip uzunca oturup döndüm.

Edebiyat gecesine gelirsek: $O$ «El-islah»a tam sekiz sum fayda sağladı, çünkü o akşam kulüp salonunda Zakir Sayidzade ${ }^{37}$ esnaflardan ve hafifmeşrep kızlardan bir topluluk teşkil edip, tiyatro oyunu sahneledi. Aslında kendisi de ilgi çekici idi. Tam 47 sum toplandi. $\mathrm{O}$ akşam tüm gençler bizim gecede idiler. Zakirlerde dans ilan edilmiş olsa da dansçı bulamamaktan dolayı gerçekleşmedi.

Bizim «edebiyat gecesi»nde Tukayev'in «Kesikbaşı» okundu (kendisi okudu). Halkın gülmekten içleri katıldı ve Tukayev'i de alkışlar ile ağırladılar. Gecenin sonuna doğru kendisi «Ben nereye gidiyorum»du, gecede şöyle ilgi çekici durumlar da oldu: Bir kâhya (önce Agufurovlar' $\mathrm{da}^{38}$ kalmış, şimdi Kazan'da kalıyor) yüzüne allık, pudra sürüp gelip, şöyle bir dans etti ki Arapların dediği gibi «Lem yera gaynez-zamani mislehü» ${ }^{39}$. Kendine has bir şekilde nasılsa başını vücuduna gömüp, kendi içine giriyor da, oradan ayak ve ellerini çıkarıp vuruyor. Herkesin dikkati ondaydı. Bu - bir. İkincisi - bir ihtiyar, uzun boylu Tatar, dans eden kızların üzerine adeta yemeğe tuz

\footnotetext{
${ }^{30}$ Dramaturg Gafur Kolehmetov'un küçük kardeşi, gençken ölür.

${ }^{31}$ Yazar Kebir Bekěr (1880-1921).

${ }^{32}$ Gaziz Gobeydullin (1887-1938).

${ }^{33}$ Soltan Rahmankoliy (1888-1916).

${ }^{34}$ Alkollü içecek satılan dükkan.

${ }^{35}$ Fehrěl İslam Agiyev — yazar, gazeteci (1887-1938).

${ }^{36}$ Yazar ve dramaturg Garif Bogdanov amaçları için çalışıyor olsa gerek. Sovyet çă̆ında mekteplerde çalışır, sonuncu yıllarda ölür.

37 Öğretmen ve yazar, 1918 yılında Astrahan'da Aklar (Beyaz Ordu yandaşları, karşı devrimciler) tarafindan öldürülmüş.

${ }^{38}$ Ekaterinburg şehrindeki büyük tüccar.

${ }^{39} \mathrm{Bu}$ zamanda bunun gibisinin görüldüğü yok idi.
} 
veya baharat serper gibi tutam tutam şekerleme saçtı, dans eden çifte göre - şimdi yanlarına geliyor da, üç tane şekerleme alıp kızın başına koyuyor. Hele birini yere düşürsünler. Tam eğlence!

«Edebiyat derneği» şimdi düzenli bir şekilde devam ediyor. Okunan şeyler o kadar çok oluyor ki, çoğu meclislerde vakit yetmiyor. Müzakereler de pek heyecanlı oluyor. Gabdulla Gıysmeti ${ }^{40}$ ile tartışmanın tamamlandığı yok. Delikanlı kendisi de şüpheye düşmeye başlamışa benziyor.

Bogdanova Gayşeler'in evleri yandı. Kendileri güçlükle pencereden çıkıp kurtuldular. «Orenbursgkaya Gazetesi»nde Kazan-Tatar piyeslerinde oynayan kızları tenkit edip yazan kişinin kim olduğu belli olsa, onu Tatar gazetelerine yazıp sağlam şekilde sövüp saymak gerekti. Bir şarlatandır. Kasim Uralets ${ }^{41}$ denen bir şarlatan Kazan'da Rus gazetelerine böyle şeyler yazıyordu. $\mathrm{Bu}$ da böyle bir Tatar kâhyası sayesinde ayakta duran biridir, elbette. Size protesto yazmak elbette farz olmasa, utancı seninle Borhan ${ }^{42}$ başına kalacak, fakat «meşhur ve büyük muharrirlerimizden» Yarulla el-Veli'nin bize verdiği lakabından pek memnun olduk. Askerde hocalık yaptığı zamanda Tatarlara ideal Tatarca namaz dersini vermek için alıştırma yapıp döner mi diye düşünüyordum. Tatarca ad vermeye de alışmışmış. Eğer ezanı da Tatarcaya aktarsa, ondan sonra hepsi büyük muharrirliğin gelişimine ulaşmış olurdu. Her şeye rağmen, öyle saf, alaylı Tatar askerleri millet için çok faydalı olurlar. Çünkü millet çocuklarına gülmek için bir şey gereksiz geliyor. Senin mektuptan sonra, ben de onunla tanışmak için pek heyecan duyup gittim (eğer isterse). Bizim görmeden tanışmamızın mukaddimesi olarak benim ismimden teşekkürünü şu sözlerle aktarırsın: «Sukonnım rılom u kalaçnıy ryad ne lezut»

Eğer bir kişi şöyle yalakalık etse, onu azarlamak ayıp olmuyor, Borhan'a selam söyle. Benim için elini sık. Sonra da mektup yazmaktan uzak durmak için mücadele et.

Hadi, canım, hoşça kal!

Mektup yaz.

\footnotetext{
${ }^{40}$ Gazeteci.

${ }^{41} \mathrm{Bu}$ konuda Fatih Emirhan'ın özel makalesi çıktı. Kara: F. Emirhan, eserler, II. T-288-290 s.

${ }^{42}$ Gazeteci Borhan Şeref, dil alimi G. Şeref' in akrabası.
} 
Fatih.

İbrahim her mektubunda sana selam yazıyor. Safiye hanımdan pek sik mektup alıyorum. O Noel Bayramına gitmiş.

27 Nisan 1909

İsmail!

İşte sana mektup. Nereden başlayıp yazayım? Bekle, buldum. Kazan'da su bu yıl çok güçsüz akıyor. Bundan dolayı bütün ayaklı kişiler eskisi gibi kayıklarda gezinemiyor, kürekler 1şıldamıyor, akordeon yankılanmıyor. Dün senin son mektubunla birlikte Burhan'dan da bir uzun mektup aldım. Zakire Hanıma ${ }^{43}$ bir teklif hazırladığını öğrenip, her nedense gönülden rahatladım, memnun oldum. Çok vakit geçmişti. Muhitte de pek başarılı olarak seçilmiş. Kisacası tencere-kapak. Sen bana «Zakire Hanım kim» sorusuna pek mufassal cevap yazarsın diye düşünüyorum. Yani sende nasıl bir intiba biraktı? Burhan'ın talihi sende de biraz olsaydı. Amin! Kazan'da senin düşündüğün cazip şeylerden biri bile yok. Herkes imtihana hazırlanıyor, imtihansız kişiler parasızlıktan keyifsiz bir şekilde yaşıyorlar.

Cenabe büyüğüm bu günlerde «Almaşınuv Könnerěnden ${ }^{44} » \mathrm{i}$ (Değişim Günlerinden) yazıp bitiriyorum. «Tatar kızı ${ }^{45}$ » isimli bir öykü yazdım, basıma gönderdim.

«El-islah» şimdi yeniden canlanıyor, paraya ihtiyacı var, sen, lütfen, nereden olursa olsun bulup kendin için de gerekli olan paran1 ${ }^{46}$ bu mektubu alınca gönder. Eğer bulabilirsen, yardım da toplayıp göndersen çok minnettar oluruz.

İbrahim'den ${ }^{47}$ mektup aldım. Paraları almış, artık çok iyiyim, diye yazıyor. Bana mekteplerinin resmi ile kartlar gönderdi. Aynı zamanda

\footnotetext{
${ }^{43}$ Zakire Şeref - Burhan Şeref' in eşi, Fatih Kerimi'nin kız kardeşi, hala sağ.

${ }^{44}$ Fatih Emirhan'ın «Yeşler» isimli piyesi.

${ }^{45}$ Fatih Emirhan' $1 n$ bu isimdeki eseri.

${ }^{46}$ İ. Aitov «El-islah»a yardım sebebiyle 50 sum söz vermiş. Söz bununla ilgili olsa gerek.

${ }^{47}$ F. Emirhan'ın kardeşi, Beyrut'ta okuduğu vakitler.
} 
senin gönderdiğin «Medrese-i $\operatorname{Han}^{48}{ }^{2}$ resmi beni nasıl düşüncelere, mülahazalara sevk etti. Yine böyle ilgi çekici durumlar olursa gönder.

Rizvan'dan ${ }^{49}$ mektup aldım. Neler yazmış: Özür dilemiş, söylenmiş, kızmış, Adı geçen Hekimcan bize hile yaptı, muhtemelen. Şimdiye kadar hiç sesi soluğu da çıkmadı. Züppe gençten bundan başka ne olur diye beklemek gerek.

Veli Apanay $^{50}$ çok zor başlayarak ekinlerle uğraşıyor, un biriktiriyorum diyor. Kendisini işe vermiş, hesapliyor. Bir Allah'a malûm.

Hokand hallerini ayrıntısıyla anlatıp, üşenmeden bir de mektup yaz. «Hanımefendi ${ }^{51} »$ sağlığına kavuştu, buna göre beni tebrik etmeye hazır!

Soltan ${ }^{52}$, kendi ifadesiyle «bütün vakitlerde sarhoş». Şimdi kendisi burada, benim yanımda, sana selam söylüyor. Tukayev de benim masanın yanında elini yanağına dayamış oturuyor, sana selam söylemiyor. Soltan şimdi kendisi söyleyip yazdırdığı söze kendisi pişman oluyor. Buna göre ben de o sözü yazmamayı hesaplıyorum.

Artık yeter. Mektup yaz!

Fatih.

6 Haziran 1923, Kazan.

Dostum Mecit, selamlar!

Ben hastalandım, yatak döşek yatıyorum. Ondan ötürü sizin edebi hayatınızda yirmi yılı doldurduğunuzu ancak dün, 5 Haziranda, yani jübile gününden iki gün sonra duydum. İște bir aydır gazeteleri elime

\footnotetext{
${ }^{48}$ Hokand Medresesi.

49 Fatih Emirhan «Millet Terekkıy İttěrüv» (Milleti Terakki Ettirmek) adlı eserini yazdığında burada Mişer talebesi obrazında kendi kendine gülmek dediği için Rizvan Aluşi kırılmış.

50 Veli Apanayev - müzisyen, mandolinci. Tatarlarda ilk telli orkestra kuranlardan.

${ }^{51}$ Söz Şemsinisa Kamalova hakkında olsa gerek.

${ }^{52}$ Soltan Rahmankoliy.
} 
alamıyorum, bütün dünya ahvalinden gafil yatıyorum. Bugün biraz daha keyifli oluşumdan istifade edip "Güç olsa da hem olmaz»" ${ }^{53}$ denen Türk atasözüne boyun eğip, size şu mektubu yazmak için oturdum. Aklım az çalışıyor, mektup karışık ve düzensiz oluyor. Lakin zararı yok, ben ancak bu mektup ile size selam ve tebriğimi gönderip, yirmi yıllık edebi hizmetinizi takdir edenlerden birisi olduğumu yazmayı istedim. Yirmi yıl diyoruz! Bizim kısa ömürlü 3540 da ölüp giden nesil için az değil.

Ben hatırlıyorum, sizin «Medrese-i Muhammediye»de önceki şiirlerinizin nasıl sevilip okunduğunu. Hayata dönüp baksan, göz açıp yummak gibi. Şu önceki şiirlerin okunmasının üzerinden yirmi yıl geçip gitmiş. Fakat şimdi, «Ak Karışık Alaca bir nesneye döndü baş». Evet, alaca bir nesneye döndü artık, fakat çoktandır mı o başlar sizinki kapkara, benimki koyu kahverengi idi!

Siz son yıllarda epey çok şey yazıp hazırladınız. Bu şair için büyük talih. İște ben şimdi ömrümün şu devrine gelip eser veremiyorum. Ancak son yıllarda «rolümü» bulup aldım, son yılların son günlerinde hakikaten yazmaya başlama dönemime gidiyorum hemen. Elbette benim de «yazmaya başlamama on yedi yıl olmuş şimdi». Farklı düşünüp eser verdim şimdiye kadar. İște ben artık hastalandım: Ben plevrit hastalığına yakalandım, az zaman sonra geliyorum. Vakti gelince, kımız içmek yararlı oluyor. Buna göre ben 18-20 Mayısta ${ }^{54}$ Ufa'ya gidip orada kımız içme meselesini deneyeceğim. Ümit ediyorum ki Ufa'ya varınca orada sizi görürüm ve o vakitte sizinle uzun bir muhasebe yaparız.

Şimdi yeniden bir kez daha sizi, edebi hizmetinizin yirmi yıllık bayramı dolayısıyla tebrik edip, yeniden uzun yıllarca şu hizmetinizin devamını diliyorum.

Selam ve saygı ile.

${ }^{53}$ Gecikmek hiç olmamasından daha iyidir.

54 Fatih Emirhan'ın hasta olup da, kendisinin anlattığına göre, mektubu yazdığında yorulmasından kaynaklı burada «mayıs» diye yazmış olsa gerek. F. Emirhan 1923 yılında Ufa'ya kımız içmeye gitmemiş olsa gerek. Çünkü arșivden bu mektubu bulunca 1962 yılında ben șair Seyfi Kudaș'a özel bir mektupla müracaat ettim. O, 1962 yılının 18 Şubatında bana yazdığ mektubunda F. Emirhan'ın Ufa'ya 1924 y1lında geldiğini, Çişme rayonu, Küçěm köyünde kımız içtiğini Başkurdistan Partisi ve hükümet yöneticileri ile rastlaştı̆̆ını Punaçarskiy ismindeki parkta Gaziz Elmöhemmedov ve Soltan Gabeșiler' in düzenlediği resitalde olduğunu söyleyip cevap yazdı. 
ÇÜTAD

Haziran 2019

Fatih Emirhan Mektupları

Fatih Zarif Oğlu Emirhan

(Fatih Emirhan).

\section{KAYNAKÇA}

Hismetullin, H. (1966). Fatih Emirhan Hatları. Kazan Utlart. Kazan: KPSS'nın Tatarstan Ölke Komitetının Gazeta Hem Jurnallar Neşriyatı. 
ÇÜTAD

Haziran 2019

Fatih Emirhan Mektupları
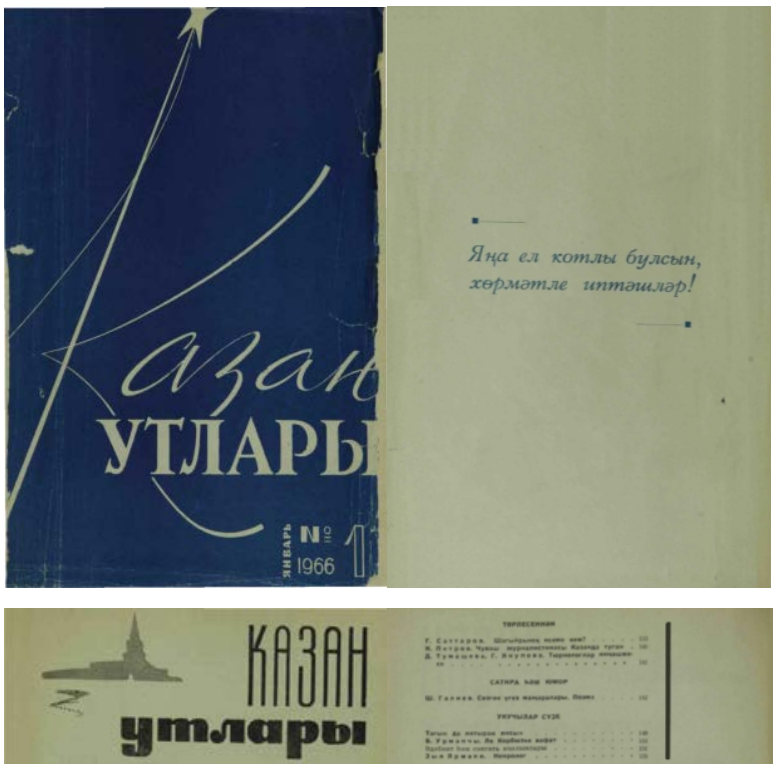

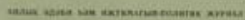

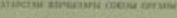

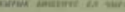

5y caisu:

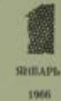

3.6-

2...…

cere -

¿

*

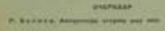

menos man 
ÇÜTAD

Haziran 2019

Fatih Emirhan Mektupları
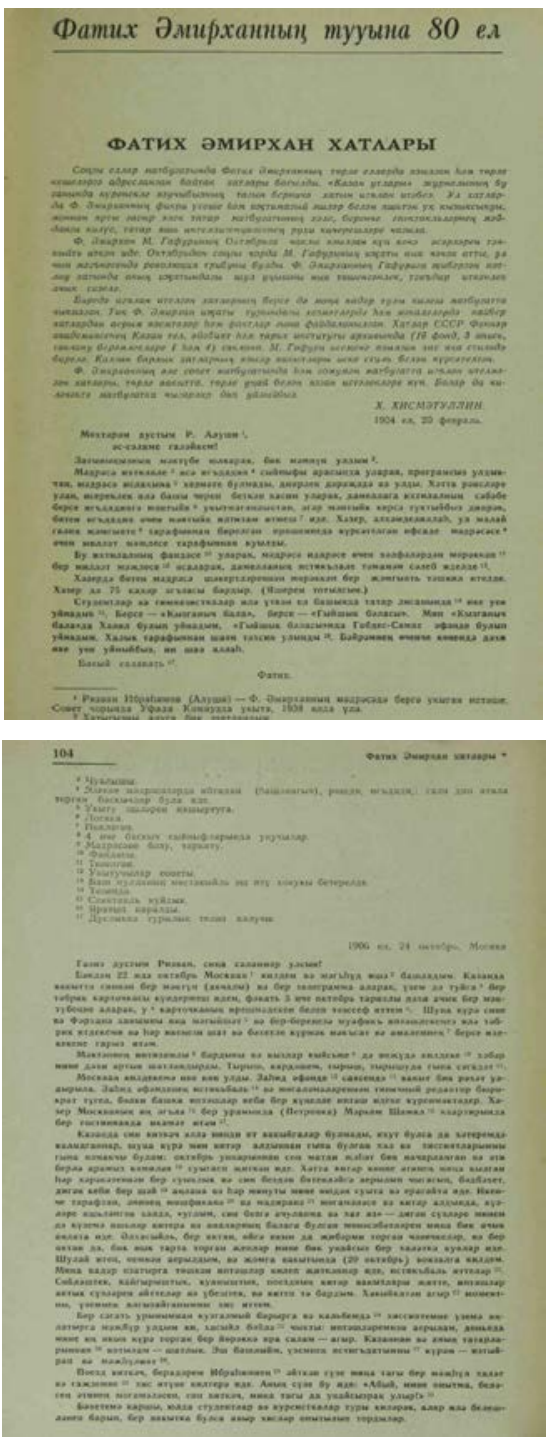
ÇÜTAD

Haziran 2019

Fatih Emirhan Mektupları
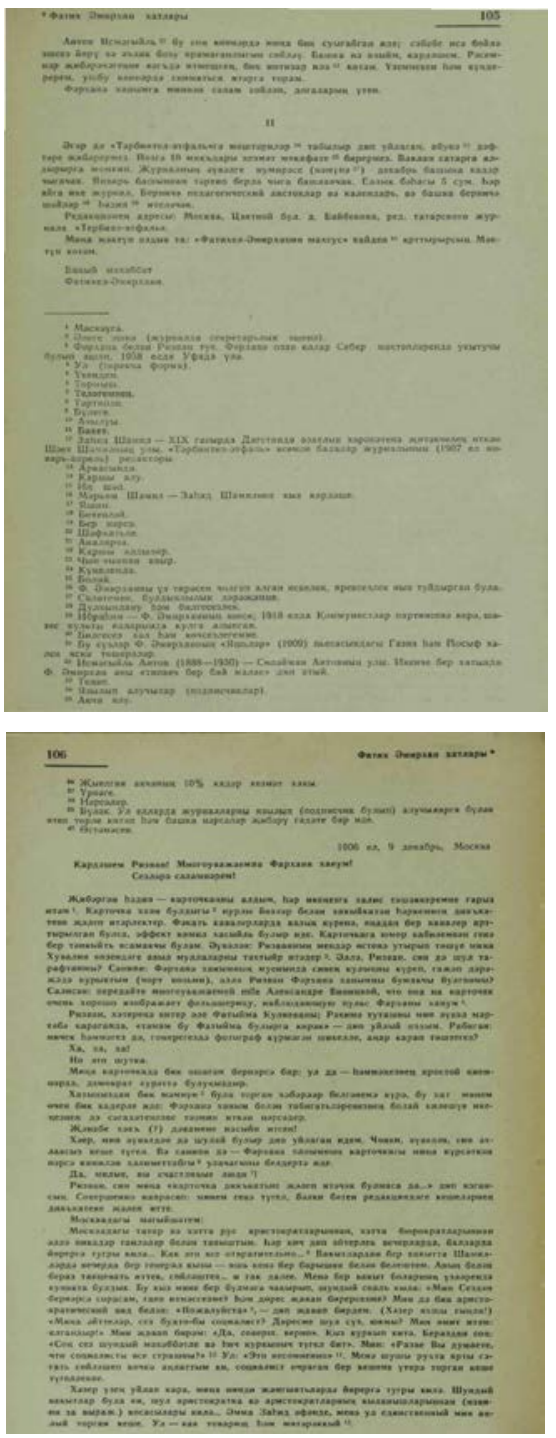
ÇÜTAD

Haziran 2019

Fatih Emirhan Mektuplar
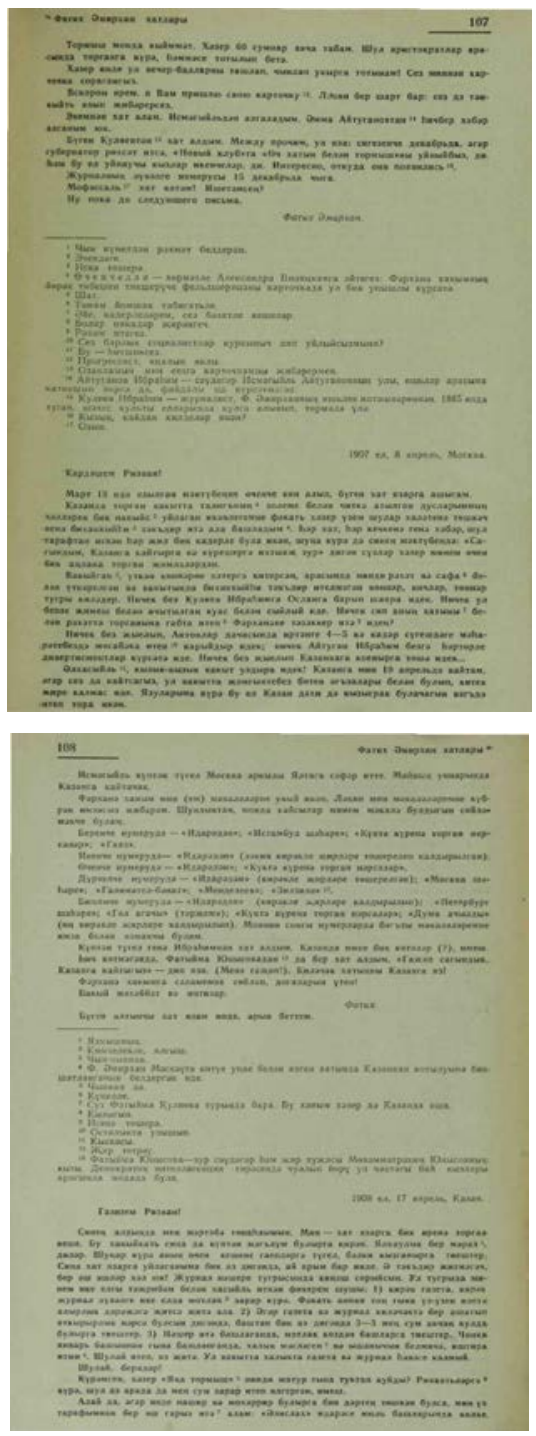
ÇÜTAD

Haziran 2019

Fatih Emirhan Mektuplar
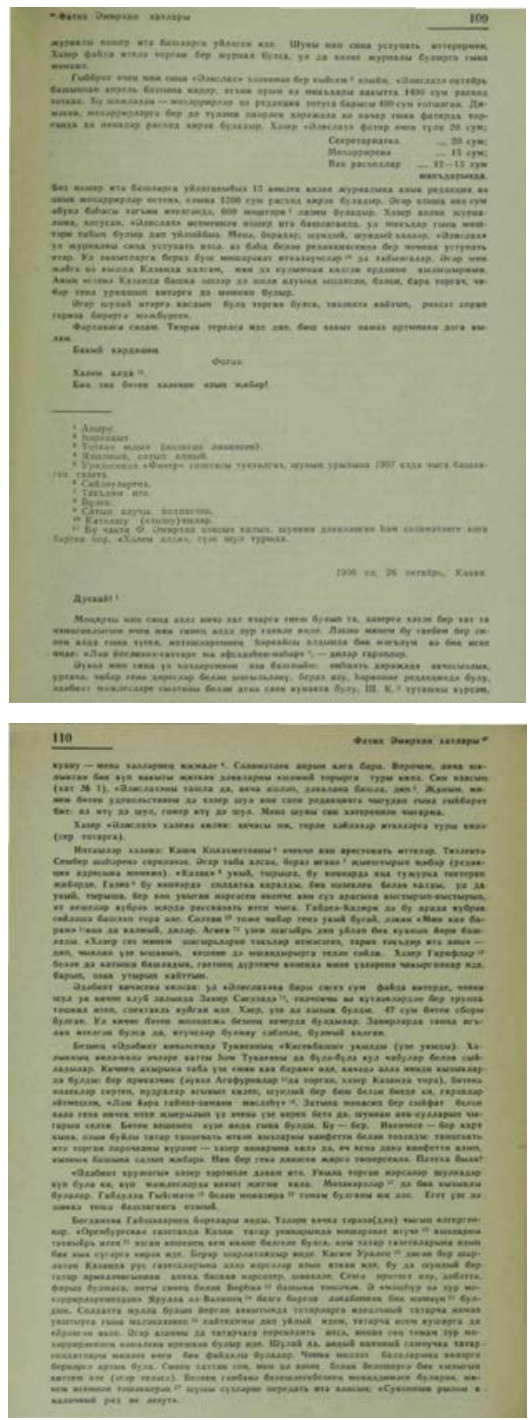
ÇÜTAD

Haziran 2019

Fatih Emirhan Mektupları
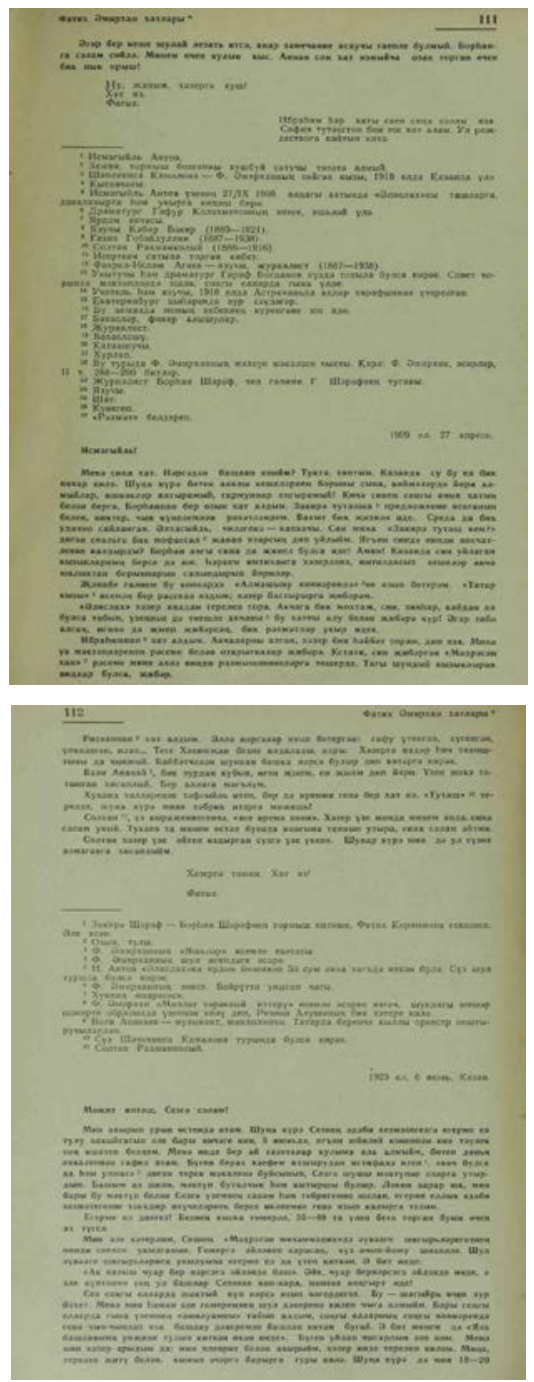
ÇÜTAD

Haziran 2019

Fatih Emirhan Mektupları

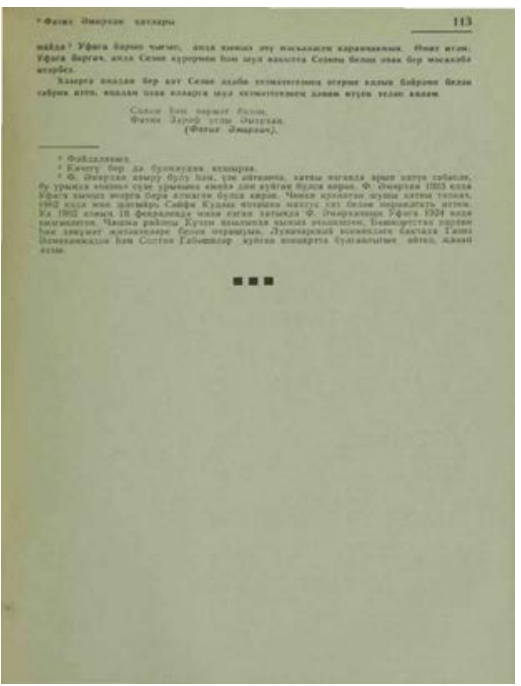

